\title{
Study of cancer incidence among 8530 male workers in eight Norwegian plants producing ferrosilicon and silicon metal
}

\author{
Ånund Hobbesland, Helge Kjuus, Dag S Thelle
}

\begin{abstract}
Objectives-To examine the association between cancer incidence, in particular incidence of lung cancer, and duration of work among employees in eight Norwegian plants producing ferrosilicon and silicon metal.

Methods-Among men first employed during 1933-91 and with at least 6 months in these plants, the incident cases of cancer during 1953-91 were obtained from The Cancer Registry of Norway. The numbers of various cancers were compared with expected figures calculated from age and calendar time specific rates for Norwegian men during the same period. Internal comparisons of rates were performed with Poisson regression analysis. The final cohort comprised 8530 men.
\end{abstract}

Results-A total of 832 cases of cancer were observed against 786 expected (standardised incidence ratio (SIR) 1.06). Among the furnace workers an increased incidence of lung cancer (SIR 1.57) and testicular cancer (SIR 2.30) was found. Internal comparisons of rates by Poisson regression analysis among the rural furnace workers showed a positive trend between incidence of lung cancer and duration of work of 1.05 (95\% confidence interval $(95 \% \mathrm{CI}) 1.00$ to 1.10$) /$ work-year. Excess cases of prostate and kidney cancer were found among blue collar nonfurnace workers, in particular among the mechanics.

Conclusion-The results suggest associations between furnace work and lung and testicular cancer, and between nonfurnace work and prostate cancer. (Occup Environ Med 1999;56:625-631)

Keywords: ferroalloy; lung; amorphous silica

Ferrosilicon ( $\mathrm{FeSi}$ ) is an alloy of silicon and iron in which the silicon content varies from $45 \%$ to $90 \%$ by weight in various products. The metal is produced by an electrometallurgical process with crystalline silica as the main raw material and coke and coal as the main reduction materials. Silicon metal (Si-met, elemental silicon) is manufactured with a similar process but without iron. Silicon metal is used in the aluminium industry, as a raw material in the electronics industry, and in the chemical industry. FeSi is mainly used in the production of steel and iron, but also in the chemical industry.

Manufacturing of ferroalloys-for example, $\mathrm{FeSi} / \mathrm{Si}$-met - has involved exposure to a mixture of gases, fumes, dusts, and physical factors. These include known and suspected carcinogens such as asbestos, crystalline silica, and electromagnetic fields. ${ }^{1-3}$ Three Norwegian studies of cancer incidence including workers in $\mathrm{FeSi} / \mathrm{Si}$-met plants have been published. ${ }^{4-6}$ An increased incidence of cancer of the lung, colon, and prostate was found in some but not all of the plants. Thus, it remained uncertain whether there was an increased risk of cancer associated with work in the $\mathrm{FeSi} / \mathrm{Si}$-met plants.

We have recently published a study on cause specific mortality among employees in 12 Norwegian ferroalloy plants, including eight $\mathrm{FeSi} /$ Si-met plants. ${ }^{7}$ Among men who had worked at the $\mathrm{FeSi} / \mathrm{Si}$-met furnaces at least 3 years the standardised mortality ratio (SMR) for all cancers was 1.10 (95\% confidence interval $(95 \%$ CI) 0.88 to 1.36 ). The SMRs for specific cancers were not examined. As the Cancer Registry of Norway has registered incident cases of cancer from 1953 we proceeded with a study of the incidence of specific cancers. The present study comprises workers from the eight FeSi/Si-met plants. The aim of this study was to examine the association between duration of work in these plants and the incidence of cancer, in particular lung cancer. The study was performed as an historical cohort study.

\section{Material and methods}

The eight FeSi/Si-met plants are located in different parts of Norway, three plants in urban and five in rural areas. Six of the plants started production before 1930, and the remaining two plants in 1964 and 1967.

EXPOSURE INFORMATION

Information on the various exposure factors is limited and concerns mainly total dust. Based upon 401 personal total dust measurements among furnace workers from three of the plants during 1974-90 the median and the 5th and 95 th percentile values were $4.0,1.2$, and $13.7 \mathrm{mg} / \mathrm{m}^{3}$. The values were declining during this period. ${ }^{8}$ Amorphous silica fume is supposed to constitute about $50 \%$ of the total dust exposure of the furnace workers. ${ }^{8}$ From total dust measurements in three plants the median exposure to amorphous silica fume for the furnace workers during 1974-91 may thus be estimated to have declined from $2.4 \mathrm{mg} / \mathrm{m}^{3}$ in 
$1974-9$ to $1.7 \mathrm{mg} / \mathrm{m}^{3}$ in $1986-90$. Corresponding emission of silica fume in an Australian plant has been shown to be an ultrafine aerosol with geometric means of the primary particle diameters from various sources ranging from 0.03 to $0.05 \mu \mathrm{m}$. $^{9}$ The diameters of the particle aggregates ranged from 0.12 to $0.18 \mu \mathrm{m}$. The exposure to crystalline silica has been low among the furnace workers (about $4 \%$ of total dust exposure) but may previously have been high for the few men who operated the quartz crushers. Asbestos was used until 1982 as an insulating material against heat and electric current. Between 1965 and 1975 several of these plants had a yearly consumption of 2-6 tonnes of asbestos. Some workers wore gloves and other protective working clothes containing asbestos. However, due to specialisation of work only a few workers, in particular mechanics, were highly exposed to asbestos. The exposure to polycyclic aromatic hydrocarbons (PAHs) among these workers has been low. A time weighted average for total PAHs of 10 $\mu \mathrm{g} / \mathrm{m}^{3}$ has been reported in preparation of tapping spouts which is one of a few jobs with a potential exposure to PAHs. ${ }^{5}$

The furnaces have increased in size and power demands from $8-10$ to $40-50 \mathrm{MW}$ which probably also has increased the exposure of the workers to electromagnetic fields (EMFs). Stationary measurements of the 50 $\mathrm{Hz}$ EMF around one of the biggest furnaces (100 $000 \mathrm{~A}, 40-50 \mathrm{MW})$ showed 500 and 50 $\mu \mathrm{T}$ at distances of 0 and $10 \mathrm{~m}$, respectively, from the wall of the furnace at the floor where the metal is drained out. ${ }^{10}$ Exposures $>1000 \mu \mathrm{T}$ may also occur in other parts of the furnace house. The electric energy is converted to heat in the furnaces which together with heat from combustion of the carbonaceous materials fuse the raw materials. This implies considerable heat radiation to the workers. It was shown in one of the plants in 1978-9 that the Botsball temperature was $>25^{\circ} \mathrm{C}$ wet globe temperature (WGT) in all work areas examined in the furnace house. ${ }^{11}$ Rectal temperatures $>38^{\circ} \mathrm{C}$ were found in all but two workers.

\section{STUDY POPULATION}

The primary male cohort consisted of 9708 men: 874 of these were removed as they were first employed before 1933; 304 (3\%) were removed due to unknown vital data or deaths before 1953. The final cohort thus consists of 8530 men employed for at least 6 months and first employed in these plants during 1933-91. Employment records were the main source of individual information on employment. Variables recorded were employee's name, date of birth, the five digit personal number, up to 10 employment periods with location of work, and the smoking habits when available. Vital status was obtained for each study subject from the records of the official population register. In Norway, people who died or emigrated before 1960 are lacking the five digit personal number. The vital data for these were individually sought by name and date of birth.

Details of cancer cases diagnosed in the period 1 January 1953 to 31 December 1991 were obtained from the Cancer Registry of Norway. Cases of cancer during this period were coded according to the seventh version of the international classification of diseases (ICD-7). Information on individual date of death was supplied by linking the cohort to Statistics Norway (the national register for causes of death). In this study each man was followed up from the beginning of 1953 or if he was employed later from the first day of employment. The observation period continued until the date of death, emigration, the occurrence of one or two primary cancers (in analyses of specific site or total cancer, respectively), or the end date of the study. Seven cases of cancer which had occurred after 1953 but before the start of employment were omitted, but the men were followed up for a second cancer. The median duration of total employment was 5.2 years. The median age at start of first and end of last employment were 26.2 and 37.3 years, respectively. The median duration of follow up was 22.5 years. The cohort was observed for 193930 person-years. A total of 5357 men $(63 \%)$ had worked for at least 3 years in any department. Among these men the median duration of total employment was 11.8 years.

EXPOSURE VARIABLE

Individual information on employment periods and work areas (departments) was used as a proxy for true exposure information as industrial hygiene data were sparse and did not exist before 1974. Quantitative exposure estimation was therefore not performed and should probably not be attempted without measurement data. ${ }^{12}$ We have previously presented a semiquantitative job exposure matrix for exposure to amorphous silica fume in these plants. ${ }^{8}$ This matrix was not applied in this study as adjustments for other relevant exposures - for example, asbestos-could not be performed. There has also been very little evidence in general of any carcinogenic potential of amorphous silica. ${ }^{13}$ However, the health effects have not been well studied and the health hazards may not be the same for all the various polymorphs of amorphous silica. ${ }^{13} 14$

The concern about possible health hazards in these plants has been particularly related to furnace work. The cancer incidence among men who ever had been a furnace worker was therefore of particular interest. By contrast with these workers we defined a group of blue collar workers who never had been furnace workers, non-furnace workers. This group was composed of mechanics, electricians, transport workers, raw material workers, packers, and building and construction workers. Most manual workers in these plants were unskilled, with the exception of electricians, and the selection among the unskilled workers to furnace or non-furnace work was assumed to be random, at least before 1980 .

\section{DATA ANALYSIS}

Standardised incidence ratios (SIRs) for various sites of cancer were calculated as the ratio between the observed and the expected 
Table 1 Observed (Obs) and expected (Exp) numbers of all cancers 1953-91 in 8530 employees in eight FeSi/Si-met plants

\begin{tabular}{|c|c|c|c|c|}
\hline & Obs & Exp & SIR & $95 \% C I$ \\
\hline Total & 832 & 785.83 & 1.06 & 0.99 to 1.13 \\
\hline \multicolumn{5}{|c|}{ Year of first employment: } \\
\hline $1933-52$ & 415 & 390.83 & 1.06 & 0.96 to 1.17 \\
\hline $1933-59$ & 137 & 144.79 & 0.95 & 0.80 to 1.12 \\
\hline 1960-69 & 205 & 187.23 & 1.09 & 0.95 to 1.26 \\
\hline $1970-91$ & 75 & 62.96 & 1.19 & 0.94 to 1.49 \\
\hline \multicolumn{5}{|c|}{ Year of diagnosis of cancer: } \\
\hline 1953-59 & 11 & 21.45 & 0.51 & 0.26 to 0.92 \\
\hline $1960-69$ & 74 & 87.60 & 0.84 & 0.66 to 1.06 \\
\hline $1970-79$ & 224 & 214.66 & 1.04 & 0.92 to 1.19 \\
\hline $1980-81$ & 523 & 462.20 & 1.13 & 1.04 to 1.23 \\
\hline \multicolumn{5}{|c|}{ Duration of employment (y): } \\
\hline$<3$ & 233 & 227.09 & 1.03 & 0.90 to 1.17 \\
\hline $3-9$ & 223 & 207.13 & 1.08 & 0.94 to 1.23 \\
\hline $10-19$ & 179 & 149.73 & 1.20 & 1.03 to 1.38 \\
\hline$\geqslant 20$ & 197 & 201.86 & 0.98 & 0.85 to 1.12 \\
\hline
\end{tabular}

SIR=standardised incidence ratio.

number of cancers. The expected numbers were calculated from national male 5 year age specific incidences for each year from 1953 to 1991, submitted from the Cancer Registry of Norway. A 95\% CI was calculated for all SIRs by assuming a Poisson distribution of the observed numbers and assuming the expected numbers to be constants. For results with $\leqslant 100$ cases exact CIs were calculated. In situations with $>100$ cases approximate $95 \%$ CIs were calculated with the formula $\exp (\ln (\mathrm{SIR}) \pm$ $1.96 \mathrm{SE})$ with $\mathrm{SE}$ for $\ln (\mathrm{SIR})$ estimated to be $1 / \mathrm{D}^{1 / 2}$ where $\mathrm{D}$ is the number of cancers. ${ }^{15}$ The DATAB version $1.8 \mathrm{w}$ program of the Epicure program package was used to calculate the observed and expected values for SIR analyses. ${ }^{16}$

Event-time tables were stratified by both fixed and time dependent variables. For the furnace and non-furnace workers the observation period and duration of work were defined according to the employment periods in the actual type of work. In these analyses other kinds of work were not considered in the calculation of duration of specific work. The association between cancer incidence and duration of work was studied with application of lags or exposure windows in some analyses. ${ }^{17}{ }^{18}$ In the exposure window analyses only exposure or work during a period defined by its duration (the width of the window) and the duration before observation were considered to be aetiologically relevant and categorised as exposure or work. A distinction between short and long term employment was made at 3 years. Some analyses were limited to men employed for the first time in this industry in 1953 or later as this was the first year of observation for cases of cancer.

Internal comparisons of rates with Poisson regression analysis were performed with the AMFIT version $1.8 \mathrm{w}$ program of the Epicure program package. These analyses were performed on event-time tables created with the DATAB program. Each cell of an event-time table contained time at risk, number of events, and the various covariate values-for example, the risk set updated mean of duration of work. Test for a linear trend between lung cancer and duration of work was performed by calculating the $\mathrm{p}$ value for the likelihood ratio test (LRT) when the continuous variable duration of work was withdrawn from the final model. The RRs and the $95 \%$ CIs were calculated by the program.

Individual data on smoking were available only for 226 men (28.4\%) with a cancer and were thus insufficient for adjustments in the analyses.

\section{Results}

A total of 832 cases of cancer were observed in 796 men (SIR 1.06, 95\% CI 0.99 to 1.13, table 1). The SIR became unchanged if the observation was ended after the first case of cancer. The overall cancer incidence was highest (SIR 1.19) among men who were first employed during 1970-91. Analyses by year of occurrence of cancer among all employees showed steadily increasing SIRs from 0.51 in 1953-59 to 1.13 in $1980-91$. The SIRs increased also through the first three categories of duration of employment, but was close to the expected value in the fourth category.

Table 2 Observed (Obs) and expected (Exp) numbers of various cancers in furnace and non-furnace workers in eight FeSi/Si-met plants

\begin{tabular}{|c|c|c|c|c|c|c|c|c|}
\hline \multirow[b]{2}{*}{ Cancer site (ICD-7) } & \multicolumn{4}{|c|}{ Furnace workers $(n=2534)$} & \multicolumn{4}{|c|}{ Non-furnace workers $(n=3384)$} \\
\hline & Obs & $\operatorname{Exp}$ & $S I R$ & $95 \% C I$ & Obs & $\operatorname{Exp}$ & $S I R$ & $95 \% C I$ \\
\hline Oesophagus (150) & 1 & 2.65 & 0.38 & 0.01 to 2.10 & 5 & 4.12 & 1.21 & 0.39 to 2.83 \\
\hline Stomach (151) & 12 & 18.49 & 0.65 & 0.34 to 1.13 & 23 & 29.06 & 0.79 & 0.50 to 1.19 \\
\hline Colon (153) & 17 & 17.18 & 0.99 & 0.58 to 1.58 & 29 & 26.63 & 1.09 & 0.73 to 1.56 \\
\hline Rectum (154) & 15 & 11.63 & 1.29 & 0.72 to 2.13 & 18 & 17.99 & 1.00 & 0.59 to 1.58 \\
\hline Pancreas (157) & 8 & 7.96 & 1.01 & 0.43 to 1.98 & 12 & 12.33 & 0.97 & 0.50 to 1.70 \\
\hline Nose, accessory sinuses (160) & 0 & 0.74 & 0.00 & 0.00 to 5.01 & 2 & 1.13 & 1.77 & 0.21 to 6.38 \\
\hline Larynx (161) & 2 & 3.07 & 0.65 & 0.08 to 2.35 & 5 & 4.61 & 1.08 & 0.35 to 2.53 \\
\hline Trachea, bronchus, lung (162) & 46 & 29.34 & 1.57 & 1.15 to 2.09 & 53 & 44.41 & 1.19 & 0.89 to 1.56 \\
\hline Pleura (163) & 1 & 0.79 & 1.27 & 0.03 to 7.09 & 2 & 1.19 & 1.68 & 0.20 to 6.07 \\
\hline Prostate (177) & 42 & 35.79 & 1.17 & 0.85 to 1.59 & 80 & 57.78 & 1.38 & 1.10 to 1.72 \\
\hline Testis (178) & 9 & 3.91 & 2.30 & 1.05 to 4.37 & 4 & 5.53 & 0.72 & 0.20 to 1.85 \\
\hline Kidney, ureter (180) & 11 & 8.27 & 1.33 & 0.66 to 2.38 & 21 & 12.57 & 1.67 & 1.03 to 2.55 \\
\hline Urinary bladder (181) & 14 & 15.27 & 0.92 & 0.50 to 1.54 & 25 & 23.55 & 1.06 & 0.69 to 1.57 \\
\hline Malignant melanoma (190) & 7 & 7.86 & 0.89 & 0.36 to 1.84 & 17 & 11.65 & 1.46 & 0.85 to 2.34 \\
\hline Skin (191; excluding basal cell carcinoma) & 5 & 6.16 & 0.81 & 0.26 to 1.90 & 6 & 9.76 & 0.61 & 0.23 to 1.34 \\
\hline Nervous system (193) & 5 & 6.98 & 0.72 & 0.23 to 1.67 & 11 & 10.31 & 1.07 & 0.53 to 1.91 \\
\hline Other, unspecified sites (199) & 9 & 8.59 & 1.05 & 0.48 to 1.99 & 20 & 13.43 & 1.49 & 0.91 to 2.30 \\
\hline Lymphoma (200-202) & 7 & 8.17 & 0.86 & 0.34 to 1.77 & 11 & 12.29 & 0.89 & 0.45 to 1.60 \\
\hline Multiple myeloma (203) & 7 & 3.87 & 1.81 & 0.73 to 3.73 & 4 & 6.03 & 0.66 & 0.18 to 1.70 \\
\hline Leukaemia (204) & 4 & 5.44 & 0.74 & 0.20 to 1.88 & 4 & 8.50 & 0.47 & 0.13 to 1.21 \\
\hline All sites (140-209) & 243 & 220.50 & 1.10 & 0.97 to 1.25 & 370 & 340.10 & 1.09 & 0.98 to 1.20 \\
\hline
\end{tabular}


Table 3 Observed (Obs) and expected (Exp) numbers of lung cancer in furnace and non-furnace workers in eight FeSi/Si-met plants

\begin{tabular}{|c|c|c|c|c|c|c|c|c|}
\hline & \multicolumn{4}{|c|}{ Furnace workers $(n=2534)$} & \multicolumn{4}{|c|}{ Non-furnace workers $(n=3384)$} \\
\hline & Obs & $\operatorname{Exp}$ & $S I R$ & $95 \% C I$ & Obs & $\operatorname{Exp}$ & SIR & $95 \% C I$ \\
\hline Total & 46 & 29.35 & 1.57 & 1.15 to 2.09 & 53 & 44.39 & 1.19 & 0.89 to 1.56 \\
\hline \multicolumn{9}{|c|}{ Year of first employment: } \\
\hline $1933-52$ & 14 & 13.79 & 1.02 & 0.56 to 1.70 & 25 & 20.11 & 1.24 & 0.80 to 1.84 \\
\hline $1953-59$ & 10 & 4.79 & 2.09 & 1.00 to 3.84 & 11 & 8.59 & 1.28 & 0.64 to 2.29 \\
\hline $1960-69$ & 16 & 7.87 & 2.03 & 1.16 to 3.30 & 13 & 12.23 & 1.06 & 0.57 to 1.82 \\
\hline $1970-91$ & 6 & 2.89 & 2.08 & 0.76 to 4.52 & 4 & 3.46 & 1.16 & 0.32 to 2.96 \\
\hline \multicolumn{9}{|c|}{ Time since start of work $(y)$ : } \\
\hline$<10$ & 7 & 3.29 & 2.13 & 0.86 to 4.39 & 2 & 4.60 & 0.43 & 0.05 to 1.57 \\
\hline $10-19$ & 14 & 6.48 & 2.16 & 1.18 to 3.62 & 13 & 9.85 & 1.32 & 0.70 to 2.26 \\
\hline $20-29$ & 10 & 7.94 & 1.26 & 0.60 to 2.32 & 14 & 12.50 & 1.12 & 0.61 to 1.88 \\
\hline$\geqslant 30$ & 15 & 11.64 & 1.29 & 0.72 to 2.13 & 24 & 17.45 & 1.38 & 0.88 to 2.05 \\
\hline \multicolumn{9}{|c|}{ Duration of work (y): } \\
\hline$<3$ & 17 & 9.93 & 1.71 & 1.00 to 2.74 & 16 & 11.86 & 1.35 & 0.77 to 2.19 \\
\hline $3-9$ & 10 & 8.85 & 1.13 & 0.54 to 2.08 & 11 & 11.62 & 0.95 & 0.47 to 1.69 \\
\hline $10-19$ & 13 & 5.55 & 2.34 & 1.25 to 4.01 & 16 & 8.98 & 1.78 & 1.02 to 2.89 \\
\hline$\geqslant 20$ & 6 & 5.02 & 1.19 & 0.44 to 2.60 & 10 & 11.93 & 0.84 & 0.40 to 1.54 \\
\hline
\end{tabular}

Table 4 Observed (Obs) numbers of lung cancer, the rate ratios (RRs) from Poisson regression modelling, and the standardised incidence ratios (SIRs) by cumulative duration of furnace work among 1433 furnace workers in five rural FeSi/Si-met plants

\begin{tabular}{llllll}
\hline Duration of furnace work $(y)$ & Obs & $R R^{\star}$ & $95 \%$ CI & SIR & $95 \%$ CI \\
\hline$<3$ & 2 & 1.00 & - & 0.52 & 0.06 to 1.87 \\
$3-9$ & 5 & 1.95 & 0.37 to 10.2 & 0.87 & 0.28 to 2.04 \\
$10-19$ & 7 & 5.25 & 1.03 to 26.7 & 1.92 & 0.77 to 3.96 \\
$\geqslant 20$ & 6 & 4.85 & 0.90 to 26.3 & 1.97 & 0.72 to 4.29 \\
Trend slopet & & 1.05 & 1.00 to 1.10 & & \\
\hline
\end{tabular}

$\star$ Rate ratios adjusted for age $(<60,60-69,70-79, \geqslant 80$ years $)$, calendar time $(1953-69,1970-79$ $1980-91)$, and duration of follow up $(<10,10-19,20-29, \geqslant 30$ years).

†Rate ratio per year of work.

Table 2 presents the incidence of the various sites of cancer among the furnace and nonfurnace workers. Among the furnace workers increased SIRs were found for lung cancer (SIR 1.57), and testicular cancer (SIR 2.30). Among the non-furnace workers increased SIRs were found for prostate cancer (SIR 1.38), and cancer of the kidney and ureter (SIR 1.67). An increased total cancer SIR of 1.36 (95\% CI 1.03 to 1.76 ) was found for furnace work of 10-19 years. The corresponding SIR for non-furnace work was 1.13 (95\% CI 0.90 to 1.41$)$. Further Poisson regression analyses of rates of all cancers by duration of work among the furnace and non-furnace workers (separately) adjusted for age, calendar time, and duration of follow up did not show any associations with duration of work, neither with nor without application of lags of 10 or 20 years in any of the groups.

Table 3 shows further analyses of lung cancer in these groups. For furnace workers first employed before 1953 (which was the start of the observation period) the number of lung cancers was not increased (SIR 1.02), but SIRs of 2.09, 2.03 and 2.08 were found among men recruited during the remaining periods. This pattern by year of first employment was not found among the non-furnace workers. Analyses of the incidence of lung cancer by time since the start of furnace work showed SIR values of 2.13 and 2.16 for the two first decades, respectively, whereas the corresponding SIR values for non-furnace work were 0.43 and 1.32. Analyses of the incidence of lung cancer by duration of work showed increased incidence for short term furnace work (SIR 1.71) and for both furnace and non-furnace
Table 5 Observed (Obs) and expected (Exp) numbers of testicular cancers with SIRs in $2006 \mathrm{FeSi} / \mathrm{Si}$-met furnace workers employed in 1953 or later

\begin{tabular}{|c|c|c|c|c|}
\hline & Obs & $\operatorname{Exp}$ & SIR & $95 \% C I$ \\
\hline Total & 9 & 3.22 & 2.80 & 1.28 to 5.31 \\
\hline \multicolumn{5}{|c|}{ Time since start of furnace work (y): } \\
\hline$<5$ & 5 & 0.85 & 5.88 & 1.91 to 13.7 \\
\hline $5-9$ & 2 & 0.89 & 2.25 & 0.27 to 8.13 \\
\hline $10-19$ & 2 & 1.12 & 1.78 & 0.22 to 6.44 \\
\hline$\geqslant 20$ & 0 & 0.36 & 0.00 & 0.00 to 10.3 \\
\hline \multicolumn{5}{|c|}{ Age at risk of cancer $(y)$ : } \\
\hline$<20$ & 0 & 0.01 & 0.00 & 0.00 to 267 \\
\hline $20-29$ & 6 & 0.92 & 6.50 & 2.39 to 14.2 \\
\hline $30-39$ & 2 & 1.22 & 1.64 & 0.20 to 5.93 \\
\hline$\geqslant 40$ & 1 & 1.06 & 0.95 & 0.02 to 5.28 \\
\hline \multicolumn{5}{|c|}{ Duration of work (y) in exposure window $0-5 \mathrm{y}$ : } \\
\hline 0 & 2 & 1.31 & 1.53 & 0.19 to 5.53 \\
\hline $0.1-5.0$ & 7 & 1.91 & 3.67 & 1.48 to 7.56 \\
\hline
\end{tabular}

work of 10-19 years (SIR values 2.34 and 1.78, respectively).

The incidence of lung cancer among furnace workers in the three urban plants might be particularly distorted due to confounding as a high SIR value of 2.47 (95\% CI 1.38 to 4.08 ) was found for short term work. This excess of lung cancer is probably explained by confounding and not by work exposures as high SIRs for lung cancer were found both for furnace and non-furnace short term workers in the urban plants (SIRs 2.47 and 1.93) whereas low SIR values were found for both groups in the rural plants (SIRs 0.52 and 0.59 , respectively). Further, the incidence of all cancers was increased in the total group of urban furnace workers (SIR 1.22) but not among all rural furnace workers (SIR 1.01). Due to these results we omitted the urban furnace workers in the following analyses of lung cancer. Table 4 shows the incidence of lung cancer among the rural furnace workers in four categories of duration of work. A significantly $(p=0.03)$ increased RR of the incidence of lung cancer of $1.05 /$ work-year was found. A reanalysis with a lag of 10 years for duration of furnace work gave a non-significant and slightly weaker trend slope of 1.04 (95\% CI 0.98 to 1.09). Further Poisson regression analyses (with adjustments as presented in table 4) with comparisons of the rates of lung cancer between the 1433 furnace and 2033 non-furnace workers in the rural plants showed very close rates for the category $<10$ years of work (RR 0.95 (95\% CI 0.36 to 2.50$)$ ). However, for furnace work versus non-furnace work of $\geqslant 10$ years an RR of 1.96 (95\% CI 0.93 to 41.2 ) was found.

The further analyses of the incidence of testicular cancer was restricted to 2006 men hired for the first time in 1953 or later as excess cancers were found during the first years after employment (table 5). Five cases occurred during the first five years after the start of furnace work (SIR 5.88). Six cases occurred among men 20-9 years old (SIR 6.50), and seven of the nine cases had been employed in furnace work during the past 5 years before the cancer occurred (SIR 3.67). However, any positive association with duration of work in this period was not found. Four of the nine testicular tumours were seminomas, one was an embryonal carcinoma, two were teratomas, and two unspecified tumours. 
Table 6 Observed (Obs) and expected (Exp) numbers of prostate and kidney cancers with SIRs in 3384 non-furnace workers in eight $\mathrm{FeSi} / \mathrm{Si}$-met plants

\begin{tabular}{|c|c|c|c|c|c|c|c|c|}
\hline & \multicolumn{4}{|c|}{ Prostate } & \multicolumn{4}{|c|}{ Kidney, ureter } \\
\hline & Obs & $\operatorname{Exp}$ & $S I R$ & $95 \% C I$ & Obs & $\operatorname{Exp}$ & $S I R$ & $95 \% C I$ \\
\hline Total & 80 & 57.76 & 1.39 & 1.10 to 1.72 & 21 & 12.57 & 1.67 & 1.03 to 2.55 \\
\hline \multicolumn{9}{|l|}{ Year of first employment: } \\
\hline $1933-52$ & 48 & 27.82 & 1.73 & 1.27 to 2.29 & 8 & 5.62 & 1.42 & 0.61 to 2.80 \\
\hline $1953-59$ & 9 & 10.61 & 0.85 & 0.39 to 1.61 & 5 & 2.45 & 2.04 & 0.66 to 4.76 \\
\hline $1960-69$ & 20 & 16.04 & 1.25 & 0.76 to 1.93 & 7 & 3.46 & 2.02 & 0.81 to 4.17 \\
\hline $1970-91$ & 3 & 3.29 & 0.91 & 0.19 to 2.66 & 1 & 1.04 & 0.96 & 0.02 to 5.37 \\
\hline \multicolumn{9}{|l|}{ Time since start of work $(\mathrm{y})$ : } \\
\hline$<10$ & 2 & 4.10 & 0.49 & 0.06 to 1.76 & 2 & 1.45 & 1.38 & 0.17 to 4.98 \\
\hline $10-19$ & 15 & 12.17 & 1.23 & 0.69 to 2.03 & 3 & 2.94 & 1.02 & 0.21 to 2.98 \\
\hline $20-29$ & 22 & 15.92 & 1.38 & 0.87 to 2.09 & 8 & 3.57 & 2.24 & 0.97 to 4.42 \\
\hline$\geqslant 30$ & 41 & 25.57 & 1.60 & 1.15 to 2.18 & 8 & 4.61 & 1.73 & 0.75 to 3.42 \\
\hline \multicolumn{9}{|l|}{ Duration of work (y) lagged with $20 \mathrm{y}$ : } \\
\hline 0 & 17 & 15.72 & 1.08 & 0.63 to 1.73 & 5 & 4.26 & 1.17 & 0.38 to 2.74 \\
\hline $0.1-9.9$ & 35 & 26.42 & 1.32 & 0.92 to 1.84 & 11 & 5.67 & 1.94 & 0.97 to 3.47 \\
\hline$\geqslant 10$ & 28 & 15.63 & 1.79 & 1.19 to 2.59 & 5 & 2.65 & 1.89 & 0.61 to 4.40 \\
\hline \multicolumn{9}{|l|}{ Subgroups of non-furnace workers: } \\
\hline Mechanics $(n=1153)$ & 20 & 11.95 & 1.67 & 1.02 to 2.58 & 9 & 3.08 & 2.92 & 1.33 to 5.54 \\
\hline Building and construction $(n=637)$ & 17 & 17.15 & 0.99 & 0.58 to 1.59 & 4 & 3.26 & 1.23 & 0.33 to 3.15 \\
\hline Transport workers $(n=633)$ & 15 & 9.39 & 1.60 & 0.89 to 2.63 & 5 & 2.25 & 2.23 & 0.72 to 5.20 \\
\hline Electricians $(n=452)$ & 9 & 3.72 & 2.42 & 1.11 to 4.59 & 3 & 1.06 & 2.84 & 0.59 to 8.31 \\
\hline Packers $(n=373)$ & 12 & 8.63 & 1.39 & 0.72 to 2.43 & 1 & 1.79 & 0.56 & 0.01 to 3.12 \\
\hline Raw material workers $(n=173)$ & 8 & 5.37 & 1.49 & 0.64 to 2.93 & 0 & 0.97 & 0.00 & 0.00 to 3.80 \\
\hline
\end{tabular}

Table 6 shows that the incidence of prostate cancer among the non-furnace workers was increased among men hired before 1953 (SIR $1.73)$, for the period $\geqslant 30$ years after start of work (SIR 1.60), and for duration of work of $\geqslant 10$ years when a lag of 20 years was applied in the analysis (SIR 1.79). For the various groups of non-furnace workers the incidence of prostate cancer was significantly increased among mechanics (SIR 1.67) and electricians (SIR 2.42). Further Poisson regression analyses in all non-furnace workers showed an RR of prostate cancer of 1.03/work-year (95\% CI 1.00 to 1.06 ) when a lag of 20 years was applied and adjusted for age, calendar time, and duration of follow up. Non-significantly increased SIRs of cancer of the kidney and ureter were found for all non-furnace workers $\geqslant 20$ years after start of work. However, there was no obvious association with duration of work. Among the various groups of workers a significantly increased incidence was found only among the mechanics (SIR 2.92). The incidence of lung cancer was not increased among the mechanics (SIR 1.22, 95\% CI 0.65 to 2.09).

The cancer incidence in three other groups of production workers included in the cohort is presented in table 7 . Among 529 men who had ever been a ferrochromium ( $\mathrm{FeCr}$ ) furnace worker (from two plants) a significant excess of prostate cancer was found (SIR 1.65). The five

Table 7 Observed (Obs) and expected (Exp) numbers of cancers with SIRs in three other groups of production workers in eight FeSi/Si-met plants

\begin{tabular}{lrrrl}
\hline Cancer site (ICD-7) & Obs & Exp & SIR & 95\% CI \\
\hline Ferrochromium furnace workers (n=529) & & & & \\
$\quad$ All sites (140-209) & 76 & 80.78 & 1.06 & 0.85 to 1.31 \\
$\quad$ Stomach (151) & 13 & 10.89 & 1.02 & 0.41 to 2.09 \\
$\quad$ Trachea, bronchus, lung (162) & 23 & 13.97 & 1.19 & 0.63 to 2.03 \\
$\quad$ Prostate (177) & 5 & 3.01 & 1.66 & 0.54 to 3.88 \\
$\quad$ Kidney, ureter (180) & 35 & 27.20 & 1.29 & 0.90 to 1.79 \\
Electrode paste production workers (n=345) & 6 & 3.53 & 1.70 & 0.62 to 3.70 \\
$\quad$ All sites (140-209) & 4 & 1.86 & 2.15 & 0.59 to 5.51 \\
$\quad$ Trachea, bronchus, lung (162) & & & & \\
$\quad$ Urinary bladder (181) & 3 & 3.45 & 0.87 & 0.18 to 2.54 \\
Ferrovanadium furnace workers (n=66) & & & & \\
$\quad$ All sites (140-209) & & &
\end{tabular}

cancers of the kidney and ureter occurred all among long term furnace workers (SIR 2.33). Among 345 electrode paste production workers non-significantly increased SIRs were found for all cancers (SIR 1.29), lung cancer (SIR 1.70), and cancer of the urinary bladder (SIR 2.15). Among the long term workers in this group the corresponding SIRs were 1.09, 1.35, and 3.34, respectively. Among 66 ferrovanadium furnace workers only three cases of cancer were found (SIR 0.87).

\section{Discussion}

The main findings from this study were the excess cases of lung and testicular cancer among the furnace workers, the positive association between the RRs of lung cancer and the duration of furnace work in the rural plants, and the increased incidence of prostate cancer and cancer of the kidney and ureter among the non-furnace workers.

The results indicate an association between furnace work and lung cancer and support the hypothesis that some exposure factors connected with $\mathrm{FeSi} / \mathrm{Si}$-met furnace work increase the risk of lung cancer. The observed trend slope of 1.05 is close to the trends of the lung cancer mortality that was found in a cohort of 2570 white male workers in the diatomaceous earth industry in California. ${ }^{19}$ As in our study these men were exposed to both amorphous and crystalline silica but with a considerably higher exposure to crystalline silica (range of crystalline content $1 \%-25 \%$ of total dust). In this study and in a later study including 2342 men from the same industry, positive doseresponse relations were found for lung cancer mortality with cumulative exposure to respirable crystalline silica. ${ }^{20}$ However, exposure to crystalline silica can probably not explain our results. The available measurements of exposure to total crystalline silica among the $\mathrm{FeSi} / \mathrm{Si}$-met furnace workers indicate values of only $0.10-0.20 \mathrm{mg} / \mathrm{m}^{3}$. The main dust exposure to the furnace workers is assumed to be the amorphous silica fume emissions which is 
different from the diatomaceous earth polymorph of amorphous silica. The potential role of the exposure to amorphous silica fume on the incidence of lung cancer remains uncertain due to the scanty previous studies in this field, the lack of real exposure data, and the lack of confounding information. An effect on the rates of lung cancer from exposure to asbestos cannot be ruled out, but the SIR of 1.27 (one case) for malignant mesothelioma among the furnace workers supports the initial suggestion of low exposure to asbestos.

Our results are in accordance with studies from other related industries - such as chromium smelter workers, ${ }^{62122}$ iron and steel workers, ${ }^{23}{ }^{24}$ and silicon carbide production workers. ${ }^{25}$ The results from the present study do not indicate an association between $\mathrm{FeCr}$ furnace work and lung cancer.

The excess cases of testicular cancer among the $\mathrm{FeSi} / \mathrm{Si}$-met furnace workers was not expected and may have occurred by chance. This is also supported by the finding that seven of the nine cases occurred in men employed for the first time in 1970 or later (SIR 4.10).

However, the high incidences for the first 5 years after the start of furnace work and for furnace work of any duration during the last 5 years before cancer occurred may indicate an association with work. These workers are regularly exposed to heat ${ }^{11}$ which has been associated with increased risk of testicular cancer. ${ }^{26-28}$ Exposure to electromagnetic fields has also been associated with development of testicular cancer, in particular with non-seminoma, ${ }^{29}$ whereas excess seminomas have been found among metal workers. ${ }^{30}$ Only one of the nine furnace workers with testicular cancer had died of the disease (during 1962-1990). Thus, in cancer mortality studies in other industrial groups an increased incidence of testicular cancers may have passed unnoticed.

The increased incidence of prostate cancer among the non-furnace workers and the association with duration or work suggest an association with work exposures. Excess cases of prostate cancer were also found in the $\mathrm{FeCr}$ furnace workers and have also previously been found. ${ }^{56}$ The results are compatible with previous case-control studies where slightly increased risks of prostate cancer have been found for metal workers and for exposure to metallic dust, liquid fuel combustion products, lubricating oils and greases, and polyaromatic hydrocarbons from coal. ${ }^{31} 32$ The increased incidence of kidney cancer among the nonfurnace workers was confined to a small excess of cases which occurred particularly among the mechanics. Further analyses did not indicate any associations between kidney cancer and duration of work, neither among all nonfurnace workers, nor among the mechanics. The excess kidney cancers have therefore an uncertain association with work exposures.

The furnace workers have also been exposed to high magnetic fields for most of the working day (about 50-500 $\mu$ Tesla). Increased numbers of leukaemia and brain cancers have been reported in some previous studies among subjects exposed to EMFs. ${ }^{3}$ No excess of leukae- mia or cancers of the nervous system was found among the furnace and non-furnace workers when compared with the national rates. The cancer incidence among furnace and nonfurnace workers was also analysed together with furnace and non-furnace workers in four manganese producing plants with corresponding exposure to EMFs. ${ }^{33}$ The combined SIRs were all below 1.00 and thus did not support the hypothesis that exposure to EMFs increases the risk of leukaemia or brain cancer.

For the electrode paste production workers no conclusion can be drawn on an association between work exposures and lung cancer due to the low number of cases and the lack of information on confounding factors. The incidence of urinary bladder cancer among the long term workers is compatible with previous studies which have indicated that exposure to PAHs is a risk factor for bladder cancer. ${ }^{34} \mathrm{~A}$ study of biomarkers of exposure to PAHs in a subgroup of these workers found a mean particulate exposure to PAH of $14.4 \mu \mathrm{g} / \mathrm{m}^{3}$ (range $4.3-84.6 \mu \mathrm{g} / \mathrm{m}^{3}$ )..$^{35}$

A previous study of vanadium in blood and urine among ferrovanadium production workers found a mean vanadium concentration in the blood of $35.7 \mathrm{nmol} / 1$ among 11 people in this department. The mean blood vanadium concentration in a comparison group of six workers in a pig iron department was 20.2 $\mathrm{nmol} / 1 .{ }^{36}$ Among all workers in this plant, which mainly has produced $\mathrm{FeSi} / \mathrm{Si}$-met, a small excess of kidney cancer has been previously reported. ${ }^{37}$ However, none of the kidney cancers appeared among the ferrovanadium production workers.

VALIDITY ASPECTS

The analyses by year of cancer occurrence showed that for the period 1953-9 an overall decreased incidence of cancer was found (table 1). This may be caused by systematic errors due to (a) lower detection or reporting of cases of cancer among these workers compared with the general population, (b) selective loss of employment records for men with a cancer during this period, or (c) (probably most important) a deficiency in the procedure of identifying cohort members registered with a cancer in the Cancer Registry which for the period before 1960 had to be performed manually. Such information bias may have decreased the overall SIR.

The design of this study with recruitment of workers from 1933 combined with start of observation for a cancer from 1953 may have involved a selection bias among those who were employed for the first time during 1933-52. This may be suspected as furnace workers recruited before 1953 had an incidence of lung cancer close to the expected value whereas SIRs of 2.03-2.09 were found for workers recruited in the remaining periods. This potential bias may have decreased the overall and lung cancer SIRs.

The most important bias probably concerns confounding, particularly as individual smoking habits were not available. Among men who were $\leqslant 50$ years in 1989-90 and employed in 
four of these plants at that time the median 5 year birth cohort proportion of smokers was $58 \%$ among furnace workers, $44 \%$ in the nonfurnace workers, and $40 \%$ in the general population. ${ }^{8}$ The increased incidence of lung cancer among the furnace workers may thus be partly explained by the increased prevalence of smoking in this group.

The application of employment or work duration as a proxy for exposure in these plants has probably diminished the true underlying exposure-response associations. Only occasionally will exposure duration yield a higher relative risk than exposure measures based on measures of intensity of exposure. ${ }^{38}$ Another disadvantage of the lack of real exposure variables is that the results have only a minor significance for workers outside this industry.

In summary, we found excess cases of lung and testicular cancer among the furnace workers. Some results indicate an association with furnace work for both cancer sites, although causal factors cannot be identified. Excess cases of prostate and kidney cancer were found among the non-furnace workers. An association was indicated between duration of non-furnace work and prostate cancer, but no association was found for kidney cancer.

This project has been supported by grants from the Work Environment Fund of the Confederation of Norwegian Business and Industry (NHO). We are grateful to the staff at the Cancer Registry of Norway for help with identification of people, linking of the cohort, and compilation of the national cancer rates, and to Ole Tormod Fure at the Safety, Health and Environmental Secretariat for the Norwegian Smelters for his assistance in the cooperation with participating plants and the financial support.

1 Hammond EC, Selikoff IJ, Seidman H. Asbestos exposure, cigarette smoking, and death rates. Ann NY Acad Sci 1979;300:473-90.

2 Silica, evaluation. In: Silica, some silicates, coal dust and para-aramid fibrils. IARC Monogr Eval Carcinog Risks Hum 1997;68:210-1.

3 Thériault G. Electromagnetic fields and cancer: a critical review of occupational studies. Stockholm, Sweden: The 25th International Congress on Occupational Health, 1996.

4 Langård S, Andersen A, Gylseth B. Incidence of cancer among ferrochromium and ferrosilicon workers. $\mathrm{Br} F$ Ind Med 1980;37:114-20.

5 Kjuus $\mathrm{H}$, Andersen A, Langård S, et al. Cancer incidence among workers in the Norwegian ferroalloy industry. $B r \mathcal{F}$ Ind Med 1986;43:227-36.

6 Langård S, Andersen A, Ravnestad J. Incidence of cancer among ferrochromium and ferrosilicon workers: an ex-

7 Hobbesland Å, Kjuus H, Thelle DS. A study of mortality among 14730 male workers in 12 Norwegian ferroalloy plants: cohort characteristics and the main causes of death Occup Environ Med 1996;53:540-6.

8 Hobbesland Å, Kjuus H, Thelle DS. Mortality from non-malignant respiratory diseases among male workers in Norwegian ferroalloy plants. Scand $\mathcal{F}$ Work Environ Health 1997;23:342-50.

9 Cunningham EA, Jablonski W, Todd JJ. Electron microscopy studies of silica fume emissions from a silicon smelter in Southern Tasmania, Australia. Am Ind Hyg Assoc $尹$ 1996;57:1024-34.

10 Thommesen G, Bjølseth PS. Statiske og lavfrekvente magnetfelt $i$ norske smelte- og elektrolyseverk (Static and low frequency
magnetic fields in Norwegian alloy and electrolysis plants). magnetic fields in Norwegian alloy and electrolysis plants). Report no 1, 1992. (In Norwegian with summary in Report

11 Rodal K. Heat stress in Norwegian Industry. In: Rodal K, ed. Stress monitoring in the workplace. Boca Raton, Florida: CRC Press, 1993:9-16.
12 Stewart PA, Lees PSJ, Francis M. Quantification of historical exposures in occupational cohort studies. Scand $\mathcal{F}$ Work Environ Health 1996;22:405-14.

13 McLaughlin JK, Chow WH, Levy LS. Amorphous silica: a review of health effects from inhalation exposure with particular reference to cancer. $\mathcal{f}$ Toxicol Environ Health 1997;50:553-66.

14 Cunningham EA, Todd JJ, Jablonski W. Was there sufficient justification for the 10 -fold increase in the TLV for silica fume? A critical review. Am f Ind Med 1998;33:212-23.

15 Breslow NE, Day NE. The standardized mortality ratio (SMR). In: Statistical methods in cancer research. Vol II The design and analysis of cohort studies. IARC Sci Publ 1987;82:65-8.

16 Preston DL, Lubin JH, Pierce DA, et al. Epicure. Seattle, WA: Hirosoft, 1993.

17 Checkoway H, Pearce N, Hickey JLS, et al. Latency analysis in occupational epidemiology. Arch Environ Health 1990; 45:95-100.

18 Pearce N. Methodological problems of time-related variables in occupational cohort studies. Rev Epidémiol Santé Publique 1992;40:S43-54.

19 Checkoway H, Heyer NJ, Demers PA, et al. Mortality among workers in the diatomaceous earth industry. $\mathrm{Br} F$ Ind Med 1993;50:586-97.

20 Checkoway H, Heyer NJ, Seixas NS, et al. Dose-response associations of silica with nonmalignant respiratory disease and lung cancer mortality in the diatomaceous earth industry. Am $\mathcal{F}$ Epidemiol 1997;145:680-8.

21 Rosenman KD, Stanbury M. Risk of lung cancer among former chromium smelter workers. Am f Ind Med 1996;29: 491-500.

22 Moulin JJ, Portefaix P, Wild P, et al. Mortality study among workers producing ferroalloys and stainless steel in France. Br f Ind Med 1990;47:537-43.

23 Sorahan T, Faux AM, Cooke MA. Mortality among a cohort of United Kingdom steel foundry workers with special reference to cancers of the stomach and lung, 1946-90. Occup Environ Med 1994;51:316-22.

24 Andjelkovich DA, Mathew RM, Richardson RB, et al. Mortality of iron foundry workers: I. Overall findings. $\mathcal{F}$ Occup Med 1990;32:529-40.

25 Infante-Rivard C, Dufresne A, Armstrong B, et al. Cohort study of silicon carbide production workers. Am $\mathcal{F}$ Epidemiol 1994;140:1009-15.

26 Lin RS, Kessler II. Epidemiologic findings in testicular cancer. Am F Epidemiol 1979;110:357.

27 Haughey BP, Graham S, Brasure J, et al. The epidemiology of testicular cancer in upstate New York. Am $\mathcal{F}$ Epidemiol 1989;130:25-36.

28 Zhang Z-F, Vena JE, Zielezny M, et al. Occupational exposure to extreme temperature and risk of testicular cancer. Arch Environ Health 1995;50:13-8.

29 Stenlund C, Floderus B. Occupational exposure to magnetic fields in relation to male breast cancer and testicular cancer: a Swedish case-control study. Cancer Causes Control 1997;8:184-91.

30 Rhomberg W, Schmoll HJ, Schneider B. High frequency of metal workers among patients with seminomatous tumors of the testis: a case-control study. Am 7 Ind Med 1995;28:79-87.

31 Van der Gulden JWJ, Kolk JJ, Verbeek ALM. Prostate cancer and work environment. F Occup Med 1992;34:402-9.

32 Aronson KJ, Siemiatycki J, Dewar R, et al. Occupational risk factors for prostate cancer: results from a case-control study in Montreal, Québec, Canada. Am f Epidemiol 1996; 143:363-73.

33 Hobbesland Å, Kjuus H, Thelle DS. Study of cancer incidence among 6363 male workers in four Norwegian erromanganese and silicomanganese producing plants. Occup Environ Med 1999;56:618-24.

34 Bonassi S, Merlo F, Pearce N, et al. Bladder cancer and occupational exposure to polycyclic aromatic hydrocarbons. Int $\mathcal{F}$ Cancer 1989;44:648-51.

35 Øvrebø S, Haugen A, Fjeldstad PE, et al. Biological monitoring of exposure to polycyclic aromatic hydrocarbon in an electrode paste plant. F Occup Med 1994;36:303-10.

36 Gylseth B, Leira HL, Steinnes E, et al. Vanadium in the blood and urine of workers in a ferroalloy plant. Scand $\mathcal{F}$ Work Environ Health 1979;5:188-94.

37 Alexander J, Andersen A, Leira HL. Increased incidence of kidney cancer among workers in a ferrovanadium plant [ [abstract\#]. Cairo, Egypt: The 20th International Congress on Occupational Health, 1981.

38 Blair A, Stewart PA. Do quantitative exposure assessments improve risk estimates in occupational studies of cancer ? Am F Ind Med 1992;21:53-63. 